\title{
Vaccination of patients with inflammatory bowel disease. Practical recommendations
}

\author{
Magda Campins ${ }^{1}$, Yolima Cossio ${ }^{1}$, Xavier Martínez $^{1}$ and Natalia Borruel ${ }^{2}$ \\ ${ }^{1}$ Department of Preventive Medicine and Epidemiology. ${ }^{2}$ Department of Digestive Diseases. Hospital Universitari Vall \\ d'Hebron. Universitat Autònoma de Barcelona. Barcelona, Spain
}

\begin{abstract}
Patients with inflammatory bowel disease (IBD) have a greater risk of infection associated with the endogenous immunosuppression brought about by their underlying disease as well as the exogenous immunosuppression resulting from their therapies. In the last few years guidelines and consensus papers have been issued on the indication of vaccines for these patients as primary prevention of infection. However, vaccine coverage is low, likely because the risk for infection and both safety and efficacy concerns regarding vaccines are scarcely perceived in such cases. The available scientific evidence shows that immunization is safe for most preparations, and bears no association with an increased risk for disease activity. This paper reviews the available scientific literature, and provides recommendations on the vaccination of adults with IBD.
\end{abstract}

Key words: Inflammatory bowel disease. Vaccination. Immunizations.

\section{INTRODUCTION}

Patients with inflammatory bowel disease (IBD), either ulcerative colitis or Crohn's disease, have a greater risk of infection associated with the endogenous immunosuppression brought about by their underlying disease as well as the exogenous suppression resulting from their therapies (1-3). Intestinal barrier impairment and malnutrition are additional risk factors

Campins M, Cossio Y, Martínez X, Borruel N. Vaccination of patients with inflammatory bowel disease. Practical recommendations. Rev Esp Enferm Dig 2013;105:93-102.

Received: 20-12-2012

Accepted: $14-02-2013$

Correspondence: Magda Campins Martí. Department of Preventive Medicine and Epidemiology. Hospital Universitari Vall d'Hebron. Passeig de la Vall d'Hebron, 119-129. 08035 Barcelona, Spain

e-mail: mcampins@vhebron.net
(4). Although the incidence of vaccine-preventable infections in patients with IBD is not well established, severe forms of pneumococcal infection (fulminant sepsis) (5-7), pneumonia by the varicella-zoster virus $(8,9)$, hepatitis $B$ virus reactivation in patients with latent infection $(10,11)$, and a high incidence of shingles have all been described $(12,13)$. In addition, there is a high risk for cervical dysplasia and cancer $(14,15)$, particularly in women with Crohn's disease, due to a greater prevalence of infection with the human papillomavirus. The functional hyposplenism seen in patients by ulcerative colitis conditions a greater risk of infection by encapsulated bacteria (Streptococcus pneumoniae, Neisseria meningitidis and Haemophilus influenzae type b) $(1,6)$. The progressively increasing incidence of new IBD cases, the growing use of immunosuppressants, and the introduction of biological drugs (mainly anti-TNF agents) generates a high number of patients at risk of infection. Furthermore, these drugs are used earlier in the course of disease, there is a tendency to use combinations of various immunosuppressants to enhance efficacy, and maintenance programs that are key for sustained remission are employed. In the last few years guidelines and consensus papers have been issued on the indication of vaccines in these patients as primary prevention of infection $(1,16,17)$. Nevertheless, scientific evidence on vaccine response and safety is still limited.

The goal of this paper is to review the available scientific literature and to provide recommendations for vaccine use in adult patients with IBD while considering disease type and treatment as related to vaccine effectiveness and safety. Recommendations for systematic adult vaccination in Spain will be covered first, and then specific indications for patients with IBD will be reviewed.

\section{GENERAL PRINCIPLES OF VACCINATION}

Autoimmune diseases share some genetic predisposition as well as inflammatory mechanisms characterized by dys- 
regulated cytokines; similar anti-inflammatory treatments are used for their control, including corticoids, immunosuppressants, and biological therapies such as anti-TNF agents (18). Biological therapy has revolutionized the management of these conditions but its effect on immune response, which is what conditions therapeutic benefits, also results in an increased risk of infection.

Immunosuppression level depends on the intensity, duration, and type of treatment the patient receives. Immune therapy primarily alters cell immunity whereas humoral response remains more or less unchanged (18). Unfortunately, no clinical or laboratory parameters are available to accurately assess a patient's immune status. For corticoids, immunosuppression extent increases with treatment dose and duration; the exact dose and administration period necessary for systemic corticoids to suppress the immune system is unclear, but a dose equal to or high than $2 \mathrm{mg} / \mathrm{kg}$ of body weight -or a total dose equal to or high than $20 \mathrm{mg} /$ day of prednisone (or equivalent)- is considered to induce clinically significant immunosuppression (19).

Vaccine effectiveness in patients with IBD depends upon the quality of a patient's immune response to infection, as well as the extent of the immune compromise exerted by therapy on said immune response. Few studies have analyzed vaccine response in this group of patients; however, early immunization is generally recommended, preferably before immunomodulating or immunosuppressing therapy onset, and a serologic monitoring of vaccine response is advised whenever possible.

Defining adequate immunization strategies for these patients is important since vaccine coverage is usually low $(20,21)$, probably because of failure to perceive the risk of infection, and of vaccine-related safety and efficacy concerns in these cases. Fear that vaccines, particularly attenuated vaccines, may induce disease flare-ups has a relevant influence on their underutilization in patients with autoimmune disease; this notwithstanding, the available scientific evidence shows that immunization is safe and not associated with an increased risk for disease activity (22-25).

The general scheme regarding the immunization of patients with autoimmune disease is as follows:

\section{Patients receiving immunosuppressive therapy}

From a vaccination viewpoint patients are considered to be immunodepressed when on treatment with biological agents (such as infliximab, adalimumab or certolizumab) and/or immunosuppressants for maintenance (such as azathioprine, 6-mercaptopurine, methotrexate, mycophenolate, cyclosporin, tacrolimus, etc.), regardless of active substance and dose administered. Patients receiving corticoids for more than 14 days at doses equal to or high than $20 \mathrm{mg}$ /day of prednisone (or equivalent doses of other corticosteroids), as well as patients with significant malnutrition are also included (26).

Attenuated vaccines are generally contraindicated in these patients. Administration requires that at least three months have elapsed from immunosuppressive therapy discontinuation except for corticoids, whose required interval is only 1 month (26). If attenuated vaccines were administered before immunosuppressive therapy onset, at least 4 weeks should elapse for immune suppression to be initiated.

Table I shows a classification of vaccines according to antigen type and manufacturing method. The attenuated vaccines group includes: triple viral (measles mumps rubella), varicella, BCG, rotavirus, yellow fever, oral typhoid fever (Ty21a), oral poliomyelitis, and herpes zoster (not yet available in Spain).

Inactivated vaccines, polysaccharides and toxoids, may be safely administered to immunodepressed patients but immune response may be lower as compared to healthy people. These vaccines may be administered at any time or stage in the course of disease or treatment, but administration before immunosuppression onset is preferable to ensure a better immunosuppression (2 weeks earlier). Should vaccination occur during immunosuppression, a serological surveillance of response is recommended at one month following the last dose, or repeat vaccination is advised at three months after treatment (26).

\section{Adult systematic immunization schedule}

Assessing vaccination needs for any patient suffering from chronic disease requires a through vaccine history including systematic immunization. Patients with IBD, as is also the case with the general population, should receive

Table I. Classification of vaccines according to antigen type and manufacturing method

\begin{tabular}{ll}
\hline Attenuated & Inactivated \\
\hline Viral & Viral \\
\hline Yellow fever & Rabies \\
Poliomyelitis (Sabin, oral) & Influenza \\
Measles, rubella, mumps & Poliomyelitis (Salk, parenteral) \\
Varicella (chickenpox) & Hepatitis A \\
Rotavirus & Hepatitis B \\
Herpes zoster & Japanese encephalitis \\
& Central European encephalitis \\
& Papillomavirus \\
\hline Bacterial & Bacterial \\
\hline BCG & Pertussis (whole, acellular) \\
Typhoid fever (Ty21a, oral) & Tetanus, diphtheria (anatoxins) \\
& Pneumococcus \\
& Haemophilus influenzae type b \\
& Meningococcus \\
& Typhoid fever (parenteral) \\
& Cholera \\
&
\end{tabular}


their scheduled vaccines according to age and individual risk, always considering contraindications and general precautions.

Table II shows the adult vaccination schedule used in Spain (27).

An adult is considered to be adequately immunized if he or she received the following vaccines:

-3 doses of $\mathrm{DTPa} / \mathrm{dT}$, with the last reinforcing one within the last 10 years. Recently, most Autonomous Regions have deleted reinforcing doses every ten years for adults having received at least 5 doses, and only 1 or 2 additional reinforcing doses are recommended during the remaining life span.

-3 doses of poliomyelitis vaccine.

-2 doses of measles (triple viral) vaccine or documented natural immunity.

-2 doses of varicella vaccine, a history of chickenpox, or documented natural immunity.

-1 dose of influenza vaccine yearly from 60-65 years on.

- 1 dose of 23 -valent pneumococcal vaccine starting at 65 years of age.

Table II. Adult systematic immunization schedule recommended by "Sociedad Española de Medicina Preventiva, Salud Pública e Higiene". Spain, 2009

\begin{tabular}{|c|c|c|c|}
\hline & \multicolumn{3}{|c|}{ Age group } \\
\hline Vaccine & $15-49$ years & $50-64$ years & $\geq 65$ years \\
\hline \multirow{2}{*}{$\begin{array}{l}\text { Tetanus; } \\
\text { diphtheria; } \\
\text { pertussis }\end{array}$} & $\begin{array}{c}\text { dT ( } 1 \text { dose } \\
\text { every } 10 \text { years) }\end{array}$ & $\begin{array}{c}\text { dT (1 dose } \\
\text { every } 10 \text { years) }\end{array}$ & $\begin{array}{c}\mathrm{dT} \text { ( } 1 \text { dose } \\
\text { every } 10 \text { years) }\end{array}$ \\
\hline & \multicolumn{3}{|c|}{ Substitute initial dose of dT vaccine for dTpa } \\
\hline Influenza & & $\begin{array}{l}\text { Inactivated } \\
\text { influenza } \\
\text { vaccine } \\
\text { (1 dose yearly) }\end{array}$ & $\begin{array}{l}\text { Inactivated } \\
\text { influenza } \\
\text { vaccine } \\
\text { (1 dose yearly) }\end{array}$ \\
\hline Varicella & $\begin{array}{c}2 \text { doses } \\
\text { (0, } 1-2 \text { months) } \\
\text { in seronegative } \\
\text { patients }\end{array}$ & & \\
\hline $\begin{array}{l}\text { 23-valent } \\
\text { pneumococcal } \\
\text { polysacchride } \\
\text { vaccine }\end{array}$ & & & 1 dose \\
\hline $\begin{array}{l}\text { Human } \\
\text { papillomavirus }\end{array}$ & $\begin{array}{c}3 \text { doses (only } \\
\text { females } 15 \text { to } \\
25 \text { years of age) }\end{array}$ & & \\
\hline $\begin{array}{l}\text { Measles, } \\
\text { rubella, } \\
\text { mumps }\end{array}$ & $\begin{array}{c}1 \text { or } 2 \text { doses } \\
\text { in seronegative } \\
\text { patients }\end{array}$ & & \\
\hline
\end{tabular}

Adapted from: Salleras L, et al. (27).
A pre-vaccination serologic screening is recommended for patients with IBD according to clinical and immunization history regarding the following diseases: chickenpox, measles, hepatitis B, and hepatitis A.

\section{VACCINES INDICATED FOR PATIENTS WITH INFLAMMATORY BOWEL DISEASE}

Due to the specific risk of having some vaccine-preventable diseases or their complications, considering the immunization of patients with IBD is recommended against pneumococcus, influenza, hepatitis A, and hepatitis B, chickenpox, herpes zoster, and human papillomavirus. In patients on immunosuppressants vaccination against Neisseria meningitidis serogroup $\mathrm{C}$ and Haemophilus influenzae type $\mathrm{b}$ (Hib) should also be considered.

Table III shows vaccine indications and administration schedules.

\section{Vaccine against varicella and herpes zoster}

The indication of immunization against varicella in patients with IBD is based on the high risk of chickenpoxrelated complications seen in adults and immunodepressed hosts $(8,28-31)$. The presence of natural or vaccine-induced immunity using serology must be ascertained. A clinical history of varicella infection has limited sensitivity for the identification of seronegative cases (32). In case of susceptibility immunization with 2 vaccine doses (schedule: 0,1 month) should ensue. As this is an attenuated vaccine, administration is recommended at least 4 weeks before treatment onset with immunomodulators or immunosuppressors $(1,16,17)$. Should a risky exposure occur to a susceptible patient on immunosuppressants or immunomodulators post-exposure prophylaxis is advised with hyperimmune globulin (IM: $12.5 \mathrm{U} / \mathrm{kg}$; $125-625 \mathrm{U}$ ) or polyvalent immune globulin $(0.6-1.2 \mathrm{ml} / \mathrm{kg}$; maximum dose, $20 \mathrm{ml})(33,34)$.

Herpes zoster (shingles) occurs as a reactivation of latent infection with the varicella-zoster virus. One out of every three individuals will develop shingles in their lifetime, this risk being high for immunodepressed subjects (35). Studies in patients with IBD show a high incidence as compared to healthy controls (13) both for ulcerative colitis [rate ratio: 1.21 (95\% CI: 1.05-1.40)] and Crohn's disease [rate ratio: 1.61 (95\% CI: 1.35-1.92)]. Treatment with corticoids or azathioprine/6-mercaptopurine is associated with a significant risk increase [odds ratio (OR): 1.5 (95\% CI: 1.1-2.2) and OR: 3.1 (95\% CI: 1.7-5.6), respectively] (13). The use of combined therapy with two or three drugs (corticoids, immunosuppressants or anti-TNFs) renders this risk three times as high (36).

The herpes zoster vaccine reduces the incidence of this condition by $51 \%$, and that of post-herpetic neuralgia by $67 \%$ in people above 60 years of age (37). This vaccine is 
Table III. Administration schedules for vaccines indicated in patients with inflammatory bowel disease

\begin{tabular}{|c|c|c|c|}
\hline Type of vaccine & Vaccination schedule & Reinforcing dose & $\begin{array}{l}\text { Control response } \\
\text { (correlator of protection) }\end{array}$ \\
\hline Hib & 1 dose & Not needed & Yes $(0.15 \mu \mathrm{g} / \mathrm{mL})$ \\
\hline MCC & 1 dose & Not needed & No \\
\hline $\begin{array}{l}23 \mathrm{v} \text { pneumococcal } \\
\text { Pneumococcal } 13 \mathrm{v} \text { conjugate vaccine }\end{array}$ & $\begin{array}{l}\text { See table IV } \\
\text { See table IV }\end{array}$ & $\begin{array}{l}\text { See table IV } \\
\text { See table IV }\end{array}$ & No \\
\hline$H B V$ & $\begin{array}{l}\text { Schedule with minimal intervals } \\
\text { (immunocompetent subjects): } \\
\text { (3 doses: 0, 1, } 3 \text { months) } \\
\text { Double*, fast schedule } \\
\text { (immunodepressed subjects): } \\
\text { (4 double doses: } \\
\text { 0, 1, } 2 \text { and } 6 \text { months) }\end{array}$ & Not needed & $\begin{array}{c}\text { Yes } \\
\text { (anti-HBs } \geq 10 \mathrm{mlU} / \mathrm{mL})\end{array}$ \\
\hline HAV & 2 doses: 0,6 months & Not needed & $\begin{array}{c}\text { Yes } \\
(\mathrm{lgG}-\mathrm{HAV} \geq 10 \mathrm{mlU} / \mathrm{mL})\end{array}$ \\
\hline Influenza & 1 dose & Yearly & No \\
\hline$H P V$ & 3 doses: $0,1-2,6$ months & Not needed & No \\
\hline
\end{tabular}

*40 mcg.

authorized in the USA for individuals older than 50 years but is still unavailable in Spain. Administration to immunodepressed patients should be carefully considered given its attenuated nature. Corticoids at doses below $20 \mathrm{mg} / \mathrm{day}$ of prednisone or equivalent, as well as low-dose methotrexate $(\leq 0.4 \mathrm{mg} / \mathrm{kg} /$ week), azathioprine $(\leq 3 \mathrm{mg} / \mathrm{kg} / \mathrm{day})$ or 6 -mercaptopurine ( $\leq 1.5 \mathrm{mg} / \mathrm{kg} /$ day $)$ do not contraindicate immunization (35). The efficacy and safety of this vaccine in patients on anti-TNFs is unknown, hence it is recommended that vaccination take place at least one month prior to therapy onset or be delayed until 3 months after treatment discontinuation.

\section{Influenza vaccine}

The risk of flu complications in patients with IBD is poorly documented but expected to be higher than that of healthy persons. There is international consensus to recommend influenza vaccination every year to people with chronic diseases, particularly patients with immunosuppression (38).

The safety of influenza vaccines in patients with immune-mediated diseases is similar to the general population. Studies in these patients show no relationship between clinical activity and vaccination $(18,39)$. Immune response to vaccination may be diminished in patients with
IBD on immunosuppressants or immunomodulators: Mamula et al. analyzed response rates in children with IBD and observed seroconversion in 33 to $85 \%$ of vaccine recipients, with response percentage being lower in those on combined therapy with immunomodulators and infliximab (40). Recent studies with the influenza A H1N1 virus vaccine also suggest that patients on combined therapy with anti-TNF antibodies and immunosuppressants have a suboptimal response (minor seroconversion rates and geometric mean concentrations of antibodies) $(41,42)$. However, a similar study also in children reveals geometric mean concentrations of anti-hemagglutinin antibodies that are comparable in all patients regardless of treatment except for those who received anti-TNFs, where only $14 \%$ had seroprotection against the influenza $B$ strain included in the vaccine (43).

Only inactivated influenza vaccines are currently available in Spain, hence they may be yearly administrated to all patients with IBD regardless of the therapies they are on.

\section{Pneumococcal vaccine}

Patients with diseases which produce immunosuppression, could have high risk of developing pneumococcal infections, of serious forms, and of having complications. Particularly, patients on immunomodulators are considered 
at high risk regarding invasive and fulminant forms of disease (5-7). There is wide consensus on recommending pneumococcal vaccination for patients with immune-mediated disorders, particularly those receiving or apt to receive treatment with immunosuppresants or immunomodulators $(44,45)$

Immunization guidelines for patients with IBD recommend the 23-valent pneumococcal polysaccharide vaccine (PPV-23) $(16,17)$. However, data from efficacy and effectiveness studies of this vaccine within the last 30 years have been inconclusive and controversial because of discrepancies between clinical trials and observational studies. Overall, vaccine effectiveness ranges from 56 to $81 \%$ for the prevention of invasive pneumococcal disease in immunocompetent individuals $(46,47)$; however, its protective effect shrinks markedly in immune depression $(48,49)$. Melmed et al. analyzed this vaccine's immunogenicity in patients with Crohn's disease according to treatment and found adequate responses in only $45 \%$ of patients on combined therapy with anti-TNFs and immunomodulators, versus $80-85 \%$ among those receiving no immunosuppressants and healthy controls (48). Another recent study obtained similar results for patients on infliximab alone or in combination with immunosuppressants (50). On these grounds early administration, prior to treatment onset, is recommended.

The use of the 13-valent pneumococcal conjugate vaccine (PCV-13) has been recently approved for adults older than 50 years $(51,52)$. The conjugation of polysaccharides in the vaccine allows the induction of a T-cell-dependent immune response that improves immunogenicity, targets nasopharyngeal bacterial colonization, and allows the generation of immune memory when compared to non-conjugated polysaccharide vaccines (53).

Pneumococcal vaccination schedules for adults with IBD are shown in table IV according to age and treatment type. From 50 years old, single doses of PCV-13 are recommended regardless of prior pneumococcal non-conjugated poly-
Table V. Minimal intervals for pneumococcal vaccines

\begin{tabular}{lcc}
\hline $\begin{array}{l}\text { First vaccine } \\
\text { administered }\end{array}$ & $\begin{array}{c}\text { Second vaccine } \\
\text { administered }\end{array}$ & Time \\
\hline PCV-13 & PPV-23 & 2 months \\
PPV-23 & PCV-13 & 12 months \\
PPV-23 & PPV-23 & 60 months \\
\hline
\end{tabular}

saccharide vaccine doses. Minimal intervals for vaccine administration are 2 months (between PCV-13 and PPV23), 12 months (between PPV-23 and PCV-13), and 5 years (between PPV-23 and PPV-23) (52) (Table V).

\section{Hepatitis B virus (HBV) vaccine}

Although the prevalence of infection with hepatitis B virus in patients with IBD is similar to the general population $(54,55)$, a high risk of reactivation (56) and fulminant hepatitis B has been described in patients on immunomodulators $(10,11)$. In addition, these patients frequently undergo invasive procedures apt to increase viral transmission $(57,58)$.

Serologic markers of infection with hepatitis B virus should be determined in all patients with IBD susceptible subjects should be vaccinated and subsequently to assess the vaccine response $(17,44,59)$. Hepatitis B virus surface antibody levels (anti-HBs) equal to or higher than 10 $\mathrm{mIU} / \mathrm{ml}$ are considered protective (60).

The response to HBV immunization is lower in immunodepressed patients than in the general population (60). Response rate lower than $50 \%$ have been described in patients with IBD, with a significant association between vaccine response and type of treatment (61-64). Modified immunization schedules, high doses, and new adjuvanted

Table IV. Type of pneumococcal vaccine and administration schedule in patients with inflammatory bowel disease

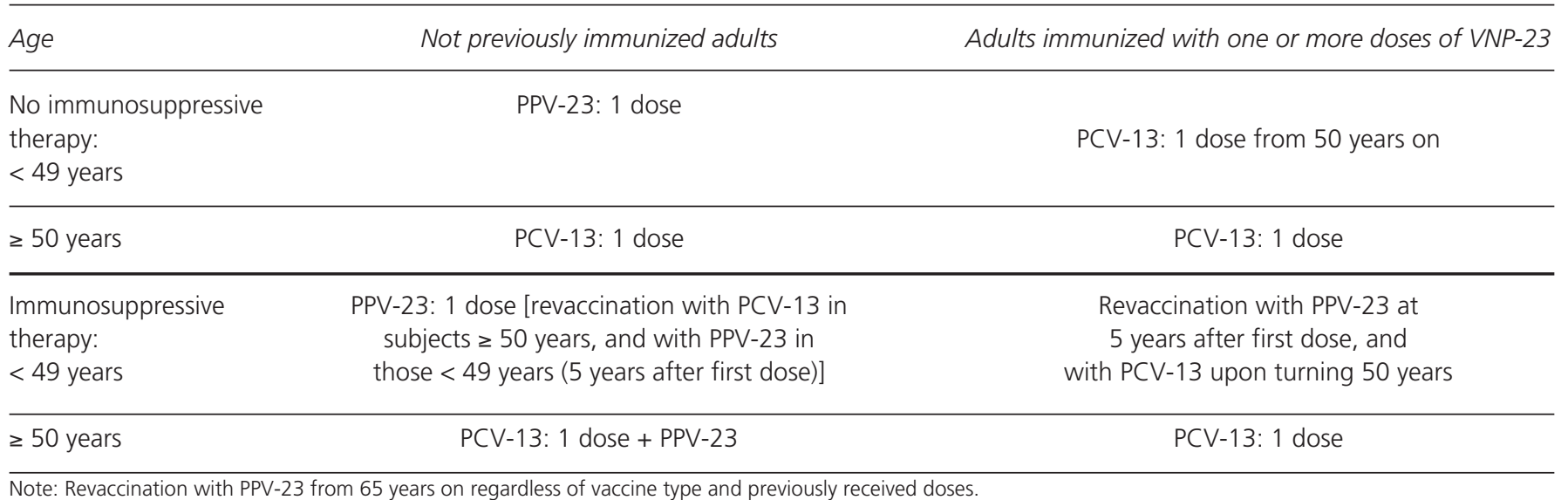


vaccines have been studied $(65,66)$ as strategies to improve response quality. Some studies suggest that schedules with double antigen doses $(40 \mathrm{mcg})$ in non-responders or subjects on immunosuppressants/immunomodulators at immunization onset do increase response rates by 30-50 \% (67-71).

Early vaccination is recommended and, if possible, end the schedule prior to initiate therapy with immunosuppressants/ immunomodulators. Vaccine response should be monitored at one to three months after the last dose (17). The standard schedule includes 3 doses with a minimum interval of one month between the first and second administrations, and of two months between the second and third ones (60). Rapid or accelerated schedules may be used in situations requiring faster immunization according to the following regimens: 0, 1, 2 and 6-12 months (rapid schedule) or 0, 7, 21 days and 12 months (accelerated schedule) (72,73). Initial vaccination using the rapid schedule and double antigen dose is recommended for immunodepressed patients, which achieve better response rates. If these patients do not develop an adequate response, should receive a second complete schedule with double antigen doses $(17,63,74,75)$.

\section{Hepatitis A virus (HAV) vaccination}

The risk of hepatitis A in patients with IBD is similar to that in the general population but the complications rate is higher in adults and immunodepressed subjects. Hence, some authors deem it appropriate to assess the presence of immunity and vaccinate susceptible individuals $(1,17)$.

In our setting, the prevalence of natural immunity is elevated in adulthood, with levels above $75 \%$ in people older than 35 years (76). Therefore, a pre-vaccination serological screening by measuring IgG antibodies is efficient for patients older than 40 years and in those coming from high endemicity areas (77). Monovalent preparations and a combined vaccine are available against hepatitis A and B (78); the hepatitis A virus vaccine is thought to be equally immunogenic in patients with IBD and healthy subjects, as revealed by a study in a pediatric population by Radzikowski et al. (79). Table III includes the recommended vaccine schedule.

\section{Human papillomavirus (HPV) vaccine}

Human papillomavirus is a necessary, albeit insufficient cause of cervical, vulvar, and anal cancer. A higher prevalence of cytological abnormalities, high-grade dysplasias, and cervical cancer has been described for women with IBD when compared to age-, race-, and parity-matched controls (42.5 vs. $7 \%$ of women with Pap smear changes, respectively), especially when on immunomodulators $(14,15,36,80,81)$. A population-based case-control study showed an increased risk of cervical cytology changes in women with Crohn's disease receiving oral contraceptives [OR: 1.66 (95\% CI: 1.08-2.54)] but not in those with ulcer- ative colitis; combined therapy with corticoids and immunosuppressants also showed a significant association [OR: 1.41 (95 \% CI: 1.09-1.81)] (14). More recently, in a casecontrol study including 22,310 patients with Crohn's disease, Marehbian et al. also witnessed that monotherapy with corticoids, immunosuppressants or anti-TNFs was associated with an increased risk of cervical dysplasia [OR: 1.5 (95 \% CI: 1.2-2.0)], whereas their combined use resulted in a high increased risk [OR: 1.8 (95\% CI: 1.1-3.0)] (36).

Several guidelines and consensus documents recommend HPV vaccination for patients with IBD, especially when on immunomodulators or immunosuppressants $(1,17,44,82)$.

No data have been yet reported on the immunogenicity and safety of this vaccine in patients with IBD; however, its efficacy and safety in the general population is high, and because it is a recombinant preparation, safety may be presumed for immunodepressed individuals $(82,83)$. Clinical trials are now ongoing in patients with HIV infection and other secondary immunodeficiencies.

\section{Meningococcus and Haemophilus influenzae type b (Hib) conjugate vaccines}

Conjugate vaccines against Haemophilus influenzae type $\mathrm{b}$ (Hib) and Meningococcus C (MCC) are included in the systematic immunization schedule for children in Spain, and are also recommended for adults at risk and immunodepressed individuals (27). In our country, patients with IBD who did not receive these vaccines during childhood and who are treated or apt to be treated with immunosuppressants, should be immunized with one dose of MCC vaccine and one dose of Hib vaccine $(1,17,84)$. The MCC vaccine will be substituted for the tetravalent conjugate vaccine in patients residing in or frequently traveling to countries with a high incidence of serogroups A, Y, and W135 (e.g., the African meningitis belt zone).

Protection duration for polysaccharide conjugate vaccines such as bivalent $(\mathrm{A}, \mathrm{C})$ and tetravalent $\left(\mathrm{A}, \mathrm{C}, \mathrm{Y}, \mathrm{W}_{135}\right)$ meningococcal vaccines decreases over time, hence patients at risk having received some of these vaccines should be re-vaccinated with the conjugate counterpart vaccines (85).

\section{VACCINES INDICATED FOR TRAVELERS WITH IBD}

The number of international travelers has spectacularly increased in the last few decades. This increased traveling, both for work- and leisure-related activities, from low endemic to high endemic countries for many transmittable diseases, as well as a more usual contact of travelers with local residents, renders it particularly important to ensure adequate protection beforehand. An adoption of preventive measures is especially important for more vulnerable individuals, including patients with IBD, and most particularly those on immunosuppressants. It is highly desirable that 


\section{Table VI. Vaccines to be used in travelers with inflammatory bowel disease. Schedule and recommendations according to immunosuppression status}

\begin{tabular}{|c|c|c|}
\hline Vaccine & Schedule & $\begin{array}{c}\text { Patients on immunosuppressive } \\
\text { therapy }\end{array}$ \\
\hline Yellow fever & 1 dose & Contraindicated \\
\hline $\begin{array}{l}\text { Japanese } \\
\text { encephalitis }\end{array}$ & $\begin{array}{c}2 \text { doses } \\
(0,28 \text { days })\end{array}$ & Not contraindicated \\
\hline $\begin{array}{l}\text { Central European } \\
\text { encephalitis }\end{array}$ & $\begin{array}{c}2 \text { doses } \\
(0,14 \text { days })\end{array}$ & Not contraindicated \\
\hline Rabies & $\begin{array}{l}\text { Pre-exposure } \\
\text { prophylaxis: } \\
0,7,21 \text { days }\end{array}$ & Not contraindicated \\
\hline \multirow[t]{2}{*}{ Typhoid fever } & $\begin{array}{c}\text { Oral attenuated } \\
3 \text { doses ( } 1 \text { comp./ } \\
\text { every other day) }\end{array}$ & Contraindicated \\
\hline & $\begin{array}{l}\text { Parenteral inactivated } \\
\qquad \text { (1 dose) }\end{array}$ & Not contraindicated \\
\hline $\begin{array}{l}\text { Meningococcal } \\
\text { conjugate } \\
\text { ACYW135 } \\
\text { vaccine }\end{array}$ & 1 dose & Not contraindicated \\
\hline
\end{tabular}

Cholera, oral 2 doses $(0,7$ days $) \quad$ Not contraindicated

patients seek help in an international vaccination unit before traveling, where immunizations indicated according to journey type and destination will be evaluated.

Table VI shows the vaccines that may be indicated for travelers with IBD.

\section{VACCINES INDICATED IN PERSONS LIVING WITH IBD PATIENTS}

Health care staff and persons who live with immunodepressed patients should receive immunization against certain diseases in order to minimize the risk of infection transmission to patients or family members.

A particular case is vaccination for infants whose mothers have IBD. Some immunosuppressants do cross the placenta and may be detected in the blood of infants up to 6 months old. This fact implies that some attenuated vaccines, such as rotavirus vaccines, are contraindicated in infants younger than 6 months should the mother be on infliximab, adalimumab or certolizumab $(17,86)$.

Table VII shows vaccines indicated for coresidents of patients with IBD.

\section{Table VII. Immunization recommendations for health care personnel and people living with inflammatory bowel disease patients}

\begin{tabular}{lc}
\hline Vaccine & Recommendations \\
\hline Influenza & All coresidents $\geq 6$ months \\
\hline $\begin{array}{l}\text { Measles } \\
\text { Rubella } \\
\text { Mumps }\end{array}$ & All non-immune coresidents $\geq 12$ months \\
\end{tabular}

Chickenpox All non-immune coresidents $\geq 12$ months (except pregnant women and immunodepressed individuals)

Hepatitis $A \quad$ Children $\geq 12$ months and adults with negative serology

\section{CONCLUSIONS}

Immunizing patients with IBD is an effective, safe preventive measure for infection control; however, vaccination coverage is usually low in this vulnerable population group. Early immunization before immunosuppressive therapy onset is associated with improved immune response. Attenuated vaccines are generally contraindicated in patients on immunosuppressants or immunomodulators. Further studies are needed to provide a deeper insight into vaccine response and vaccination schedules appropriate for these patients.

\section{REFERENCES}

1. Kotton CN. Vaccines and inflammatory bowel disease. Dig Dis 2010;28:525-35.

2. Viget N, Vernier-Massouille G, Salmon-Ceron D, Yazdanpanah Y, Colombel JF. Opportunistic infections in patients with inflammatory bowel disease: prevention and diagnosis. Gut 2008;57:549-58.

3. Toruner M, Loftus EV Jr, Harmsen WS, Zinsmeister AR, Orenstein $\mathrm{R}$, Sandborn WJ, et al. Risk factors for opportunistic infections in patients with inflammatory bowel disease. Gastroenterology 2008;134:929-36.

4. Casanova JL, Abel L. Revisiting Crohn's disease as a primary immunodeficiency of macrophages. J Exp Med 2009;206:1839-43.

5. Ritz MA, Jost R. Severe pneumococcal pneumonia following treatment with infliximab for Crohn's disease. Inflamm Bowel Dis 2001;7:327.

6. Foster KJ, Devitt N, Gallagher PJ, Abbott RM. Overwhelming pneumococcal septicaemia in a patient with ulcerative colitis and splenic atrophy. Gut 1982;23:630-2.

7. Van der Hoeven JG, de Koning J, Masclee AM, Meinders AE. Fatal pneumococcal septic shock in a patient with ulcerative colitis. Clin Infect Dis 1996;22:860-1.

8. Deutsch DE, Olson AD, Kraker S, Dickinson CJ. Overwhelming varicella pneumonia in a patient with Crohn's disease treated with 6-mercaptopurine. J Pediatr Gastroenterol Nutr 1995;20:351-3.

9. Bernal I, Domènech E, García-Planella E, Cabré E, Gassull MA. Infecciones oportunistas en pacientes con enfermedad inflamatoria intestinal bajo tratamiento inmunosupresor. Gastroenterol Hepatol 2003;26:19-22.

10. Esteve M, Saro C, Gonzalez-Huix F, Suarez F, Forné M, Viver JM. Chronic hepatitis B reactivation following infliximab therapy in Crohn's disease patients: need for primary prophylaxis. Gut 2004;53:1363-5. 
11. Milloning G, Kern M, Ludwiczek O, Nachbaur K, Vogel W. Subfulminant hepatitis B after infliximab in Crohn's disease: need for HBVscreening. World J Gastroenterol 2006;12:974-6.

12. Kotton CN. Nailing down the shingles in IBD. Inflamm Bowel Dis 2007; 13: 1178-9.

13. Gupta G, Lautenbach E, Lewis JD. Incidence and risk factors for herpes zoster among patients with inflammatory bowel disease. Clin Gastroenterol Hepatol 2006;4:1483-90.

14. Singh H, Demers AA, Nugent Z, Mahmud SM, Kliewer EV, Bernstein CN. Risk of cervical abnormalities in women with inflammatory bowel disease: a population-based nested case-control study. Gastroenterology 2009; 136:451-8.

15. Kane S, Khatibi B, Reddy D. Higher incidence of abnormal pap smears in women with inflammatory bowel disease. Am J Gastroenterol 2008:103:631-6.

16. Sands BE, Cuffari C, Katz J, Kugathasan S, Onken J, Vitek C, et al. Guidelines for immunizations in patients with inflammatory bowel disease. Inflamm Bowell Dis 2004;10:677-92

17. Wasan SK, Baker SE, Skoinik PR, Farraye FA. A practical guide to vaccinating the inflammatory bowel disease patient. Am J Gastroenterol 2010;105:1231-8.

18. Raier JF, Moutschen M, van Gompel A, van Ranst M, Louis E, Segaert $\mathrm{S}$, et al. Vaccination in patients with immune-mediated inflammatory diseases. Rheumatology 2010;49:1815-27.

19. American Academy of Pediatrics. Immunization in special clinical circumstances. In: Pickering LK, Baker CJ, Kimberlin DW, Long SS, editors. Red Book: 2009 Report of the Committee on Infectious Diseases. 28th ed. Elk Grove Village, IL: American Academy of Pediatrics; 2009.

20. Gluck T, Muller-Ladner U. Vaccination in patients with chronic rheumatic or autoinmune diseases. Clin Infect Dis 2008;46:1459-65.

21. Melmed GY, Ippoliti AF, Papadakis KA, Tran TT, Birt JL, Lee SK, et al. Patients with inflammatory bowel disease are at risk for vaccinepreventable illnesses. Am J Gastroenterol 2006;101:1834-40.

22. Wraith DC, Goldman M, Lambert PH. Vaccination and autoimmune disease: what is the evidence? Lancet 2003;362:1659-66.

23. Heijstek MW, Pileggi GC, Zonneveld-Huijssoon E, Armbrust W, Hoppenreijs EP, Uiterwaal CS, et al. Safety of measles, mumps and rubella vaccination in juvenile idiopathic arthritis. Ann Rheum Dis 2007;66:1384-7.

24. Molina V, Shoenfeld Y. Infection, vaccines and other environmental triggers of autoimmunity. Autoimmunity 2005;38:235-45.

25. Conti F, Rezai S, Valesini G. Vaccination and autoimmune rheumatic diseases. Autoimmun Rev 2008;8:124-8.

26. CDC. National Center for Immunization and Respiratory Diseases. General Recommendations on Immunization. Recommendations of the Advisory Committee on Immunization Practices (ACIP). MMWR Recomm Rep 2011;60(RR-2):1-64.

27. Salleras L, Campins M, Castrodeza J, Domínguez A, Domínguez V, Fernández-Crehuet J, et al. Calendario de vacunaciones sistemáticas del adolescente y el adulto recomendado por la Sociedad Española de Medicina Preventiva, Salud Pública e Higiene (Comité de Vacunas de la SEMPSPH). Medicina Preventiva 2010;1:76.

28. Arvin AM. Varicella-zoster virus. Clin Microbiol Rev 1996;9:361-81.

29. Balato N, Gaudiello F, Balato A, Ayala F. Development of primary varicella infection during infliximab treatment for psoriasis. J Am Acad Dermatol 2009;60:709-10.

30. Leung VS, Nguyen MT, Bush TM. Disseminated primary varicella after initiation of infliximab for Crohn's disease. Am J Gastroenterol 2004;99:2503-4.

31. Vonkeman H, ten Napel C, Rasker H, van de Laar M. Disseminated primary varicella infection during infliximab treatment. J Rheumatol 2004; 31: 2517-8.

32. Kopylov U, Levin A, Mendelson E, Dovrat S, Book M, Eliakim R, et al. Prior varicella zoster virus exposure in IBD patients treated by antiTNFs and other immunomodulators: implications for serological testing and vaccination guidelines. Aliment Pharmacol Ther 2012;36:145-50.

33. Marin M, Guris D, Chaves SS, Schmid S, Seward JF. Prevention of varicella: Recommendations of the advisory committee on immunization practices (ACIP). MMWR Recomm Rep 2007;56:1-40.

34. Oliveras M, Moraga FA. Las inmunoglobulinas en la profilaxis de la varicela. An Esp Pediatr 2000;52:71-2.

35. Harpaz R, Ortega-Sánchez IR, Seward JF. Advisory Committee on Immunization Practices (ACIP) Centers for Disease Control and Prevention (CDC). Prevention of herpes zoster: Recommendations of the
Advisory Committee on Immunization Practices (ACIP). MMWR Recomm Rep 2008;57(RR-5):1-30.

36. Marehbian J, Arrighi HM, Hass S, Tian H, Sandborn WJ. Adverse events associated with common therapy regimens for moderate to severe Crohn's disease. Am J Gastroenterol 2009;104:2524-33.

37. Oxman MN, Levin MJ, Johnson GR, Schmader KE, Straus SE, Gelb $\mathrm{LD}$, et al. A vaccine to prevent herpes zoster and postherpetic neuralgia in older adults. N Engl J Med 2005;352:2271-84.

38. Centers for Disease Control and Prevention (CDC). Prevention and control of influenza with vaccines: recommendations of the Advisory Committee on Immunization Practices (ACIP), 2011. MMWR Morb Mortal Wkly Rep 2011;60:1128-32.

39. Narula N, Yamamura DL, Marshall JK. Should my patient with inflammatory bowel disease on immunosuppressive therapy be vaccinated against influenza virus? Can J Gastroenterol 2010;24:121-5.

40. Mamula P, Markowitz JE, Piccoli DA, Klimov A, Cohen L, Baldassano RN. Immune response to influenza vaccine in pediatric patients with inflammatory bowel disease. Clin Gastroenterol Hepatol 2007;5: 851-6.

41. Andrisani G, Frasca D, Romero M, Armuzzi A, Felice C, Marzo M, et al. Immune response to influenza $\mathrm{A} / \mathrm{H} 1 \mathrm{~N} 1$ vaccine in inflammatory bowel disease patients treated with anti TNF- agents: Effects of combined therapy with immunosuppressants. J Crohns Colitis 2012 [Epub ahead of print].

42. Cullen G, Bader C, Korzenik JR, Sands BE. Serological response to the $2009 \mathrm{H} 1 \mathrm{~N} 1$ influenza vaccination in patients with inflammatory bowel disease. Gut 2012;61:385-91.

43. Lu Y, Jacobson DL, Ashworth LA, Grand RJ, Meyer AL, McNeal $\mathrm{MM}$, et al. Immune response to influenza vaccine in children with inflammatory bowel disease. Am J Gastroenterol 2009;104:444-53.

44. Rahier JF, Ben-Horin S, Chowers Y, Conlon C, De Munter P, D’Haens $\mathrm{G}$, et al. European evidence based consensus on the prevention, diagnosis and management of opportunistic infections in inflammatory bowel disease. J Crohn's Colitis 2009;3:47-91.

45. Nuorti JP, Whitney CG; Centers for Disease Control and Prevention (CDC). Updated Recommendations for Prevention of Invasive Pneumococcal Disease Among Adults Using the 23-Valent Pneumococcal Polysaccharide Vaccine (PPSV23) (ACIP). MMWR Recomm Rep 2010;59:1102-5.

46. Watson L, Wilson BJ, Waugh N. Pneumococcal polysaccharide vaccine: a systematic review of clinical effectiveness in adults. Vaccine 2002;20:2166-73.

47. Moberley SA, Holden J, Tatham DP, Andrews RM. Vaccines for preventing pneumococcal infection in adults. Cochrane Database Syst Rev 2008 Jan.

48. Melmed GY, Agarwal N, Frenck RW, Ippoliti AF, Ibanez P, Papadakis $\mathrm{KA}$, et al. Immunosuppression impairs response to pneumococcal polysaccharide vaccination in patients with inflammatory bowel disease. Am J Gastroenterol 2010;105:148-54.

49. Agarwal N, Ollington K, Kaneshiro M. Are immunosuppressive medications associated with decreased responses to routine immunizations? A systematic review. Vaccine 2012;30:1413-24.

50. Fiorino G, Peyrin-Biroulet L, Naccarato P, Szabò H, Sociale OR, Vetrano $\mathrm{S}$, et al. Effects of immunosuppression on immune response to pneumococcal vaccine in inflammatory bowel disease: A prospective study. Inflamm Bowel Dis 2012;18:1042-7.

51. Food and Drug Administration. FDA expands use of Prevnar 13 vaccine for people ages 50 and older. Silver Spring, MD: US Department of Health and Human Services, Food and Drug Administration; 2011. Disponible en: http://www.fda.gov/newsevents/newsroom/pressannouncements/ucm 285431.htm?source=govdelivery. Access Aug 18, 2012.

52. Centers for Disease Control and Prevention (CDC). Use of 13-Valent Pneumococcal Conjugate Vaccine and 23-Valent Pneumococcal Polysaccharide Vaccine for Adults with Immunocompromising Conditions: Recommendations of the Advisory Committee on Immunization Practices (ACIP). MMWR Morb Mortal Wkly Rep 2012;61:816-9.

53. Lazarus R, Clutterbuck E, Ly-Mee Yu, Bowman J, Bateman EA, Diggle L, et al. A Randomized Study Comparing Combined Pneumococcal Conjugate and Polysaccharide Vaccination Schedules in Adults. Clin Infect Dis 2011;52:736-42.

54. Loras C, Saro C, González F, Mínguez M, Merino O, Gisbert JP, et al. Prevalence and factors related to hepatitis B and C in inflammatory 
Bowel Disease Patients in Spain: A Nationwide, Multicenter Study. Am J Gastroenterol 2009;104:58-63.

55. Chevaux JB, Nani A, Oussalah A, Venard V, Bensenane M, Belle A, et al. Prevalence of hepatitis B and $\mathrm{C}$ and risk factors for non-vaccination in inflammatory bowel disease patients in Northeast France. Inflamm Bowel Dis 2010;16:916-23.

56. Pérez R, Díaz C, García F. Hepatitis B virus (HBV) reactivation in patients receiving tumor necrosis factor (TNF)-targeted therapy: Analysis of 257 cases. Medicine (Baltimore) 2011;90:359-71.

57. Bronowicki JP, Venard V, Botté C, Monhoven N, Gastin I, Choné L, et al. Patient-to-Patient Transmission of Hepatitis C Virus during Colonoscopy. N Engl J Med 1997;337:237-40.

58. Ponchon $\mathrm{T}$. Transmission of hepatitis $\mathrm{C}$ and prion diseases through digestive endoscopy: evaluation of risk and recommended practices. Endoscopy 1997;29:199-202.

59. Hou JK, Velayos F, Terrault N, Mahadevan U. Viral Hepatitis and inflammatory Bowel disease. Inflamm Bowel Dis 2010;16:925-32.

60. Mast EE, Weinbaum CM, Fiore AE, Alter MJ, Bell BP, Finelli L, et al. A comprehensive immunization strategy to eliminate transmission of hepatitis B virus infection in the United States: recommendations of the Advisory Committee on Immunization Practices (ACIP) Part II: immunization of adults. MMWR Recomm Rep 2006;55(RR-16):133.

61. Vida Pérez L, Gómez Camacho F, García Sánchez V, Iglesias Flores EM, Castillo Molina L, Cerezo Ruiz A, , et al. Adequate rate of response to hepatitis B virus vaccination in patients with inflammatory bowel disease. Med Clin (Barc) 2009;132:331-5.

62. Altunöz ME, Senate E, Ye il A, Calhan T, Ovünç AO. Patients with inflammatory bowel disease have a lower response rate to HBV vaccination compared to controls. Dig Dis Sci 2012;57:1039-44.

63. Gisbert JP, Chaparro M, Esteve M. Review article: prevention and management of hepatitis B and C infection in patients with inflammatory bowel disease. Aliment Pharmacol Ther 2011;33:619-33.

64. Gisbert JP, Villagrasa JR, Rodríguez-Nogueiras A, Chaparro M. Efficacy of hepatitis B vaccination and revaccination and factors impacting on response in patients with inflammatory bowel disease. Am J Gastroenterol 2012;107:1460-6.

65. Boland G, Beran J, Lievens M, Sasadeusz J, Dentico P, Nothdurft H, et al. Safety and immunogenicity profile of an experimental hepatitis B vaccine adjuvanted with AS04. Vaccine 2004;23:316-20.

66. Jacques P, Moens G, Desombere I, Dewijngaert J, Leroux-Roels G, Wettendorff $\mathrm{M}$, et al. The immunogenicity and reactogenicity profile of a candidate hepatitis $B$ vaccine in an adult vaccine non-responder population. Vaccine 2002;20:3644-9.

67. Cardell K, Akerlind B, Sallberg M, Frydén A. Excellent response rate to a double dose of the combined hepatitis $\mathrm{A}$ and $\mathrm{B}$ vaccine in previous nonresponders to hepatitis B vaccine. J Infect Dis 2008; 198:299-304

68. Flynn PM, Cunningham CK, Rudy B, Wilson CM, Kapogiannis B, Worrell C, et al. Hepatitis B vaccination in HIV-infected youth: a randomized trial of three regimens. J Acquir Immune Defic Syndr 2011;56:325-32.

69. Pettit NN, De Pestel DD, Malani PN, Riddell J. Factors associated with seroconversion after standard dose hepatitis B vaccination and highdose revaccination among HIV-infected patients. HIV Clin Trials 2010;11:332-9.

70. Gisbert JP, Menchén L, García-Sánchez V, Marín I, Villagrasa JR, Chaparro M. Comparison of the effectiveness of two protocols for vaccination (standard and double dosage) against hepatitis B virus in patients with inflammatory bowel disease. Aliment Pharmacol Ther 2012;35:1379-85
71. Herranz MT, Sancho del Val L, Lorenzo P, et al. Vacunación del VHB con pauta rápida y doble en pacientes con Enfermedad Inflamatoria Intestinal/ Póster. XV Reunión Nacional de la Asociación Española de Gastroenterología, Madrid 21-23 de Marzo de 2012.

72. Bock HL. Rapid hepatitis B immunisation for traveller. Comparison of two accelerated schedules with a 2-months schedule. Biodrugs 2003; 17(Supl.1):11-13.

73. Northdurft HD, Dietrich M, Zuckerman JN, Knobloch J, Kern P, Sänger R. Rapid protection against hepatits A and B using accelerated vaccination schedule. Biodrugs 2003; 17(Supl.1):15-8.

74. Chaves SS, Daniels D, Cooper BW, Malo-Schlegel S, Immunogenicity of hepatitis B vaccine among hemodialysis patients: Effect of revaccination of non-responders and duration of protection. Vaccine 2011;29:9618-23.

75. Cossio Y, Martínez X, Campins M, et al. Inmunogenicidad de la vacuna frente a hepatitis $\mathrm{B}$ en pacientes con enfermedad inflamatoria intestinal. Comunicación oral en $6^{\circ}$ Congreso de la Asociación Española de Vacunología, Santiago de Compostela 23-26 noviembre 2011.

76. Domínguez A, Bruguera M, Plans P, Espuñes J, Costa J, Plasencia A, et al. Declining hepatitis A seroprevalence in adults in Catalonia (Spain): A population-based study. BMC Infect Dis 2007;7:73-8.

77. Costas L, Vilella L, Trilla A, Serrano B, Vera I, Roldán M, et al. Vaccination strategies against hepatitis A in travelers older than 40 years: An economic evaluation. J Travel Med 2009;16:344-8.

78. Fiore AE, Wasley A, Bell BP. Prevention of hepatitis A through active or passive immunization: recommendations of the Advisory Committee on Immunization Practices (ACIP).MMWR Recomm Rep 2006;55 (RR-7):1-23.

79. Radzikowski A, Banaszkiewicz A, Tazowska-Przeorek I, Grzybowska-Chlebowczyk U, Wo H, Pytrus T, et al. Immunogenecity of hepatitis A vaccine in pediatric patients with inflammatory bowel disease. Inflamm Bowel Dis 2011;17:1117-24

80. Bhatia J, Bratcher J, Korelitz B, Vakher K, Mannor S, Shevchuk M, et al. Abnormalities of uterine cervix in women with inflammatory bowel disease. World J Gastroenterol 2006;12:6167-71.

81. Petry KU, Kochel H, Bode U, Schedel I, Niesert S, Glaubitz M, et al. Human papillomavirus is associated with the frequent detection of warty and basaloid high-grade neoplasia of the vulva and cervical neoplasia among immunocompromised women. Gynecol Oncol 1996;60: 30-4.

82. Melmed GY. Vaccination strategies for patients with inflammatory bowel disease on immunomodulators and biologics. Inflamm Bowel Dis 2009;15:1410-6

83. Markowitz LE, Dunne EF, Saraiya M, Lawson HW, Chesson H, et al, Centers for Disease Control and Prevention (CDC); Advisory Committee on Immunization Practices (ACIP). Quadrivalent Human Papillomavirus Vaccine: Recommendations of the Advisory Committee on Immunization Practices (ACIP). MMWR Recomm Rep 2007;56(RR-2):1-24.

84. Nix EB, Hawdon N, Gravelle S, Biman B, Brigden M, Malik S, et al Risk of invasive Haemophilus influenzae type b (Hib) disease in adults with secondary immunodeficiency in the post-Hib vaccine era. Clin Vaccine Immunol 2012;19:766-71.

85. Centers for Disease Control and Prevention (CDC). Updated recommendations for use of meningococcal conjugate vaccines. Advisory Committee on Immunization Practices (ACIP), 2010. MMWR Morb Mortal Wkly Rep 2011;60:72-84.

86. Mahadevan U, Cucchiara S, Hyams JS, Steinwurz F, Nuti F, Travis SP, et al. The London Position Statement of the World Congressof Gastroenterology on Biological Therapy for IBD With the European Crohn's and Colitis Organization: Pregnancy and Pediatrics. Am J Gastroenterol 2011;106:214-23. 